\title{
PENGERTIAN DAN PEMBAGIAN TAUHID
}

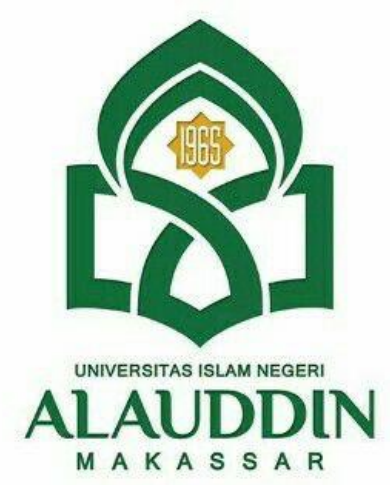

MAKALAH

Diseminarkan Pada Mata Kuliah Akidah Akhlak Program Studi

Perbankan Syariah Semester I Tahun 2021

Oleh :

Kelompok 1 (PSY-A):

Mutmainnah (90500121030)

Muh. Irwan Arfin (90500121031)

Alingka (90500121032)

Dosen Pengajar:

Supriadi Hamid, S.E.I., M.E.I

PROGRAM STUDI PERBANKAN SYARIAH FAKULTAS EKONOMI DAN BISNIS ISLAM UIN ALAUDDIN MAKASSAR 
KATA PENGANTAR

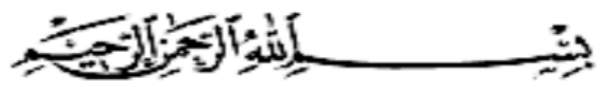

Puji syukur kehadirat Allah SWT yang telah memberikan rahmat dan hidayah-Nya sehingga saya dapat menyelesaikan tugas makalah yang berjudul Pengertian dan Pembagian Tauhid ini tepat pada waktunya.

Adapun tujuan dari penulisan dari makalah ini adalah untuk memenuhi tugas Supriadi Hamid, S.E.I., M.E.I. pada bidang studi Akidah Akhlak. Selain itu, makalah ini juga bertujuan untuk menambah wawasan tentang Tauhid bagi para pembaca dan juga bagi penulis.

Saya mengucapkan terima kasih kepada bapak Supriadi Hamid, S.E.I., M.E.I., selaku Dosen bidang studi Akidah Akhlak yang telah memberikan tugas ini sehingga dapat menambah pengetahuan dan wawasan sesuai dengan bidang studi yang saya tekuni.

Saya menyadari, makalah yang saya tulis ini masih jauh dari kata sempurna. Oleh karena itu, kritik dan saran yang membangun akan saya nantikan demi kesempurnaan makalah ini.

Makassar, 30 November 2021

Penulis 


\section{DAFTAR ISI}

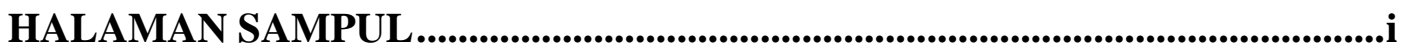

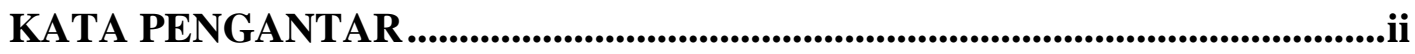

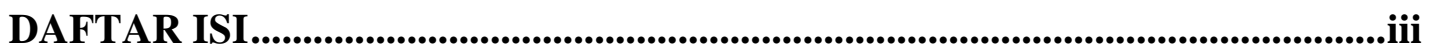

BAB I PENDAHULUAN ...............................................................................1

A. Latar Belakang ........................................................................... 1

B.. Rumusan Masalah ............................................................................ 1

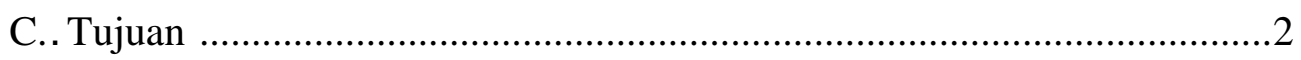

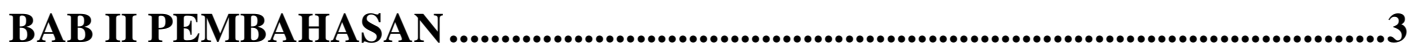

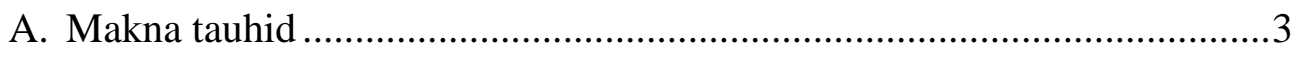

B.. Hakikat tauhid ............................................................................ 5

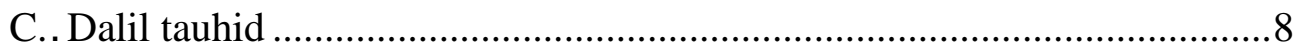

D. Kedudukan tauhid .......................................................................... 10

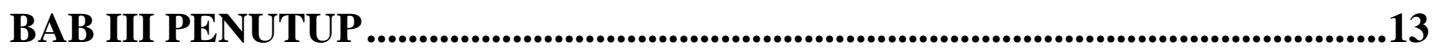

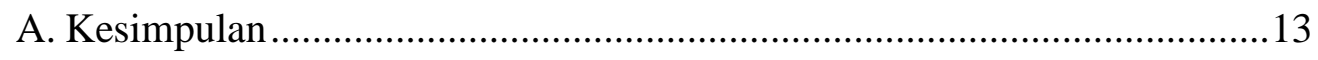

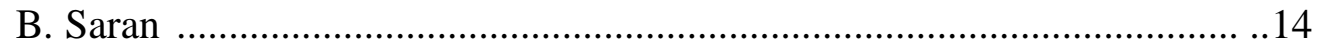

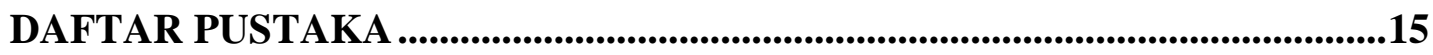




\section{BAB I \\ PENDAHULUAN}

\section{A. Latar Belakang}

Tauhid adalah ajaran inti dari konsepsi ketuhanan dalam agama Islam. Disimpulkan dalam potongan pertama kalimat syahadatain, lā ilāh illā Allāh, konsep ini mengajarkan bahwa Allah adalah satu-satunya dan segala-galanya dalam penyembahan dan penciptaan. Ujungnya jelas, yaitu menolak kemusyrikan (polytheism) karena Allah tidak mengenal imitator $^{1}$ (laysa kamitslihi syay') dan kompetitor ${ }^{2}$ (lam yakun lahukufuw a ad).

\section{B. Rumusan Masalah}

Berdasarkan latar belakang yang telah penulis uraikan, maka pokok masalah yang diangkat dalam penelitian ini adalah:

1. Makna tauhid?

2. Hakikat tauhid?

3. Dalil tentang tauhid?

4. Pembagian tauhid (Rububiyah, Uluhiyah, Asma' wa Shifat)?

\footnotetext{
${ }^{1}$ Definisi/arti kata 'imitator' di Kamus Besar Bahasa Indonesia (KBBI) adalah n orang yang meniru; peniru.

2 Definisi/arti kata 'kompetitor' di Kamus Besar Bahasa Indonesia (KBBI) adalah n orang yang bersaing.
} 


\section{Tujuan}

Berdasarkan latar belakang seperti diatas maka akan timbul beberapa tujuan penelitian sebagai berikut :

1. Untuk memenuhi tugas mata kuliah Akidah Akhlak

2. Untuk mengetahui Pengertian Tauhid dan Pembagian Tauhid 


\section{BAB II}

\section{PEMBAHASAN}

\section{A. Pengertian Tauhid}

Kata tauhid berasal dari bahasa Arab, masdar dari kata wahhada yuwahhidu. Secara etimologi, tauhid berarti keesaan.Maksudnya, iktikad atau keyakinan bahwa Allah adalah Esa; Tunggal; Satu. Pengertian ini sejalan dengan pengertian tauhid yang digunakan dalam bahasa Indonesia, yaitu "keesaan Allah"; mentauhidkan berarti "mengakui keesaan Allah; mengesakan Allah." ${ }^{\prime 3}$ Secara istilah syar"i, tauhid berarti mengesakan Allah dalam hal mencipta, menguasai, mengatur dan memurnikan (mengikhlaskan) peribadahan hanya kepada-Nya, meninggalkan penyembahan kepada selainNya serta menetapkan asma ${ }^{e e} u l$ husna dan sifat al-,,ulya bagi-Nya dan mensucikan-Nya dari kekurangan dan cacat. Asal makna "tauhid" ialah meyakinkan, bahwa Allahadalah "satu", tidak ada syarikat bagi-Nya. Oleh sebab itu, sebab dinamakan "Ilmu Tauhid", ialah karena bahagiannya yang terpenting, menetapkan sifat "wahdah" (satu) bagi Allah dalam zat-Nya dan dalam perbuatan-Nya menciptakan alam seluruhnya dan bahwa Ia sendiri-Nya pula tempat kembali segala alam ini dan penghabisan segala tujuan. ${ }^{4}$ Misalnya Muhammad Abduh menjelaskan yang artinya: "Tauhid ialah suatu ilmu yang membahas tentang wujud Allah, sifatsifat yang wajib tetap pada-Nya, sifat sifat

\footnotetext{
${ }^{3}$ Yusran Asmuni, Ilmu Tauhid,(Jakarta: RakaGrafindo Persada, 1996), cet. Ke-3, h. 1.

${ }^{4}$ Muhammad Abduh, Risalah Tauhid, (diterjemahkan oleh Firdaus AN), (Jakarta: Bulan Bintang, 1996), cet. Ke-10, h. 5.
} 
yang boleh disifatkan kepada Nya, dan tentang sifat-sifat yang sama sekali wajib dilenyapkan pada Nya. Juga membahas tentang rasulrasul Allah, meyakinkan kerasulan mereka, apa yang boleh dihubungkan (dinisbatkan) kepada mereka, dan apa yang terlarang menghubungkannya kepada diri mereka."5 Tauhid dalam kajian disebut sebagai ilmu tauhid, yang juga dinamakan sebagai ilmu kalam, karena dalam pembahasannya mengenai eksistensi Tuhan dan hal-hal yang berhubungan dengan-Nya digunakan argumentasiargumentasi filosofis dengan menggunakan logika atau mantik. Secara lebih rinciHasbi ashShiddieqi menyebutkan alasan mengapa ilmu ini disebutkan ilmu kalam, yaitu:

1. Problema yang diperselisihkan para ulama dalam ilmu ini yang menyebabkan umat Islam terpecahkan dalam beberapa golongan adalah masalahKalam Allah atau al-Qurean; apakah ia diciptakan (makhluk) atau tidak (qadim).

2. Materi-materi ilmu ini adalah teori-teori (kalam); tidak ada diantaranya yang diwujudkan ke dalam kenyataan atau diamalkan dengan anggota.

3. Ilmu ini di dalam menerangkan cara atau jalan menetapkan dalil pokokpokok akidah serupa dengan ilmu mantik.

4. Ulama-ulama mutaakhirin membicarakan di dalam ilmu ini hal-hal yang tidak dibicarakan oleh ulama salaf, seperti pentakwilan ayat-ayat mutasyabihat, pembahasan tentang pengertian qadha ${ }^{e e}$, kalam, dan lainlain.

\footnotetext{
${ }^{5}$ Yusman Asmuni, Op.cit., h. 1.
} 
Ilmu tauhid dinamakan ilmu kalam, dalam hal ini para ahli di bidang ini disebut mutakallimin.Penamaan ilmu tauhid dengan ilmu kalam sebenarnya dimaksudkan untuk membedakan atara mutakallimin dan filosof Islam.Mutakallimin dan filosof Islam mempertahankan atau memperkuat keyakinan mereka sama-sama menggunakan metode filsafat, tetapi mereka berbeda landasan awal berpijak.Mutakallimin lebih dahulu bertolak dari alQureean dan hadits, sementara filosof berpijak pada logika.Meskipun demikian, tujuan yang ingin mereka capai adalah satu, yaitu keesaan dan kemahakuasaan Allah. Dengan kata lain, mereka berbeda jalan untuk mencapai tujuan yang sama.Selanjutnya, ilmu tauhid juga dinamakan ilmu ushuluddin karena obyek bahasan utamanya adalah dasar-dasar agama yang merupakan masalah esensial dalam ajaran Islam. ${ }^{6}$ Begitu pula ketika ilmu ini disebut sebagai kajian didasarkan pada argument bahwa ,,aqaid jamak dari ,,aqidah. Aqidah berasal dari kata ,aqada yang artinya ikatan. Disebut ilmu tauhid dengan sebutan ilmu ushuluddin adalah karena pokok pembicaraannya ialah soal-soal pokok pokok kepercayaan agama yang menjadi dasar agama Islam. ${ }^{7}$

\section{B. Hakikat Tauhid}

Berdasarkan pokok bahasan dalam kajian tauhid di atas tersebut, maka tauhid diklasifikasikan kepada tauhid Rububiyah, tauhid Uluhiyah, dan tauhid Ubudiyah.

${ }^{6}$ Ibid.,h. 4-5.

${ }^{7}$ Murni, Tauhid Ilmu Kalam, (Padang : The Minangkabau Foundation Press, 2006), cet. Ke1, h. 5. 
1. Tauhid Rububiyah

Tauhid rububiyah, rububiyah adalah kata yang dinisbatkan kepada salah satu nama Allah, yaitu Rabb ${ }^{\text {ee }}$ Nama ini mempunyai beberapa arti, antara lain: AlMurabbi (pemelihara),al-Nashir (penolong), al-Malik (pemilik), alMushlih (yang memperbaiki), al-Sayyid (tuan). Dalam terminologi syarieeat Islam, istilah tauhid rububiyyah berarti percaya bahwa hanya Allah satu-satunya pencipta, pemilik, pengendali alam raya yang dengan takdirnya-Nya Ia menghidupkan dan mematikan serta mengendalikan alam dengan sunnah-sunnah-Nya".Dalam pengertian ini istilah tauhid rububiyah belum terlepas dari akar makna bahasanya.Sebab Allah adalah pemelihara makhluk, para rasul dan wali-wali-Nyadengan segala spesifikasi yang telah diberikannya kepada mereka.

Tauhid rububiyah mencakup dimensi-dimensi keimanan berikut ini: Pertama, beriman kepada perbuatan perbuatan Allah yang bersifat umum. Misalnya, menciptakan, memberi rizki, menghidupkan, mematikan, menguasai.Kedua, beriman kepada takdir Allah. Ketiga, beriman kepada zat Allah. Landasan tauhid rububiyah adalah dalil-dalil berikut:

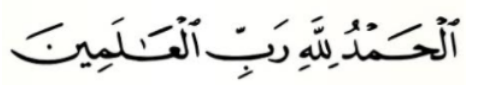

Artinya: "Segala uji Bagi Allah Rabb Semesta Alam.”(QS.Al-Fatihah: 2) 
Makna Rabb pada ayat diatas adalah bahwa Allah adalah Pencipta mereka, Yang menguasai,Yang memperbaiki dan Yang memelihara dengan segala nikmat dan anugerah-Nya. ${ }^{8}$

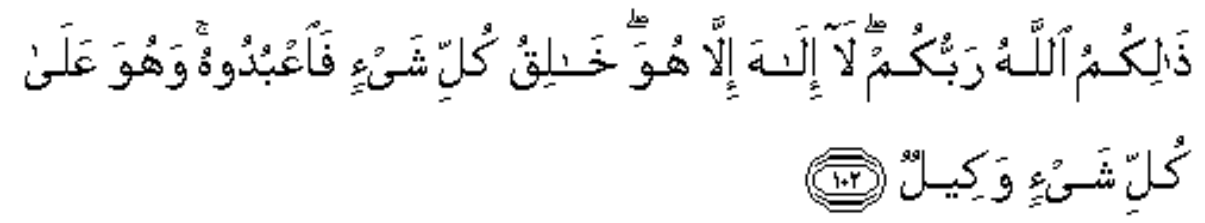

Dan Artinya: Itulah Allah Tuhan Kamu, tidak ada tuhan selain Dia, Pencipta segala sesuatu. (Q.S. Al-An'am,6:102).

2. Tauhid Uluhiyah

Tauhid uluhiyah adalah Percaya sepenuhnya bahwa Allah-lah yang berhak menerima semua peribadatan makhluk, dan hanya Allah sajalah yang sebenarnya yang harus disembah.Manusia bersujud kepada Allah, Allah tempat meminta, Allah tempat mengadukan nasibnya, manusia wajib menaati perinta dan menjauhi larangan-Nya. Semua yang berupa kebatilan langsung kepada Allah, tanpa perantara(wasilah).Allah melarang kita menyembah selain-Nya seperti menyembah batu, menyembah matahari, maupun menyembah manusia. Semua itu adalah perbuatan syirin yang sangat besar dosanya dan dibenci oleh Allah, bahkan Allah tidak akan mengampuni dosa syirik itu. ${ }^{9}$

3. Tauhid Ubudiyah

Kata ubud berasal dari kata kerja „Abada yang berarti mengabdikan diri(Ibadah). Beribadah kepada allah dengan menyembah kepada-Nya.

\footnotetext{
${ }^{8}$ Abdul Aziz bin Muhammad Alu Abdul Lathif,Pelajaran Tauhid Untuk Tingkat Lanjutan.(Jakarta:Darul Haq,1998), cet. Ke-1, h. 10

${ }^{9}$ Zainuddin,Ilmu Tauhid Lengkap, (Jakarta: Rineka Cipta,1996), cet. Ke-2, h. 17.
} 
Penyembahan disini bukan bermaksud Allah berhajat disembah hambanya karena Allah tidak ingin disembahakan tetapipenyembahan disini merupakan ketaatan,kepatuhan,ketumbuhan antara hamba dengan Tuhannya.Antara makhluk dengan khaliknya tidak ubahnya kita atau kepatuhan ketundukannya seorang anak terhadap orang tua. Seorang karyawan kepada pimpinannya yang semua kewajiban dilakukan dengan penuh rasa tanggung jawab, hanya saja didalam ketaatan menjalankan kewajiban tidak terdapat unsur benci sedikitpun kepadanya. Dengan selalu menjalankan perintah-perintahNya dan menjauhi segala laranganlaranganNya.10

\section{Dalil Tauhid}

Ilmu tauhid menetapkan aqidah-aqidah di dalam agama Islam melalui dalil atau aturan yang jelas. Terdapat sejumlah ayat di dalam Alquran yang membahas mengenai keutamaan tauhid.Tentang diberikan rasa aman dan mendapat petunjuk yang sempurna dari Allah SWT, sebagaimana firman Allah

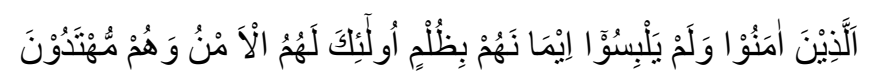

"Orang-orang yang beriman dan tidak mencampuradukkan iman mereka dengan syirik, mereka itulah orang-orang yang mendapat rasa aman dan mereka mendapat petunjuk." (QS. Al-An'am 6: Ayat 82).

Keutamaan lainnya dari tauhid adalah dihilangkan kesulitan dan kesedihannya, baik di dunia dan di akhirat. Hal ini sesuai dengan firman Allah 
pada surat Ath Thalaq berikut ini: “... Barangsiapa yang bertakwa kepada Allah niscaya Dia akan mengadakan baginya jalan keluar dan memberinya rizki dari arah yang tidak disangka-sangka..." (QS Ath Thalaq:2-3).

Selain itu dengan kita mengesakan Allah dan menerapkan ilmu Tauhid, niscaya akan diberikan kehidupan yang lebih baik di dunia dan akhirat. Hal ini sesuai dengan firman Allah di dalam surat An Nahl sebagai berikut: "Barangsiapa yang mengerjakan amal shalih, baik laki-laki maupun perempuan dalam keadaan beriman, maka pasti akan Kami berikan kepadanya kehidupan yang baik dan akan Kami beri balasan kepada mereka dengan pahala yang lebih baik dari apa yang telah mereka kerjakan.” (QS. An Nahl:97)

Masih dari surat An Nahl, terdapat ayat yang menjelaskan seruan untuk hanya beribadah kepada Allah.

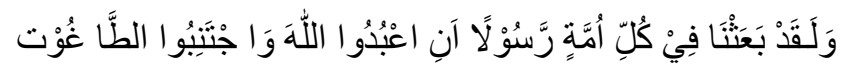

"Dan sungguh, Kami telah mengutus seorang Rasul untuk setiap umat (untuk menyerukan), "Sembahlah Allah, dan jauhilah Tagut. ${ }^{10}$.

10 Tagut (bahasa Arab: طاغوت, thaghut) adalah istilah dalam agama Islam yang merujuk kepada setiap yang disembah selain Allah yang rela dengan peribadatan yang dilakukan oleh penyembah atau pengikutnya, atau rela dengan ketaatan orang yang menaatinya dalam melawan perintah Allah. Sumber dari https://id.wikipedia.org/wiki/Tagut 


\section{Kedudukan Tauhid}

1. Tauhid Adalah Tujuan Penciptaan Manusia

Alloh berfirman, "Dan aku tidak menciptakan jin dan manusia melainkan supaya mereka menyembah kepada-Ku.” (Adz-Dzariyat: 56) maksud dari kata menyembah di ayat ini adalah mentauhidkan Alloh dalam segala macam bentuk ibadah sebagaimana telah dijelaskan oleh Ibnu Abbas rodhiyallohu 'anhu, seorang sahabat dan ahli tafsir. Ayat ini dengan tegas menyatakan bahwa tujuan penciptaan jin dan manusia di dunia ini hanya untuk beribadah kepada Alloh saja. Tidaklah mereka diciptakan untuk menghabiskan waktu kalian untuk bermain-main dan bersenangsenang belaka. Sebagaimana firman Alloh

"Dan tidaklah Kami ciptakan langit dan bumi dan segala yang ada di antara keduanya dengan bermain-main. Sekiranya Kami hendak membuat sesuatu permainan, tentulah Kami membuatnya dari sisi Kami. Jika Kami menghendaki berbuat demikian.” (Al Anbiya: 16-17).

"Maka apakah kamu mengira, bahwa sesungguhnya Kami menciptakan kamu secara main-main, dan bahwa kamu tidak akan dikembalikan kepada Kami?"” (Al-Mu'minun: 115) 
2. Tauhid Adalah Tujuan Diutusnya Para Rosul

Alloh berfirman, "Dan sungguh Kami telah mengutus rosul pada tiaptiap umat (untuk menyerukan): 'Sembahlah Alloh, dan jauhilah Thaghut itu'.” (An-Nahl: 36). Makna dari ayat ini adalah bahwa para Rosul mulai dari Nabi Nuh sampai Nabi terakhir Nabi kita Muhammad shollallohu alaihi wa sallam diutus oleh Alloh untuk mengajak kaumnya untuk beribadah hanya kepada Alloh semata dan tidak memepersekutukanNya dengan sesuatu apapun. Maka pertanyaan bagi kita sekarang adalah "Sudahkah kita memenuhi seruan Rosul kita Muhammad shollallohu alaihi wa sallam untuk beribadah hanya kepada Alloh semata? ataukah kita bersikap acuh tak acuh terhadap seruan Rosululloh ini?" Tanyakanlah hal ini pada masing-masing kita dan jujurlah...

3. Tauhid Merupakan Perintah Alloh yang Paling Utama dan Pertama

Alloh berfirman, "Sembahlah Alloh dan janganlah kamu mempersekutukan-Nya dengan sesuatu pun. Dan berbuat baiklah kepada dua orang ibu-bapa, karib-kerabat, anak-anak yatim, orang-orang miskin, tetangga yang dekat dan tetangga yang jauh, dan teman sejawat, ibnu sabil dan hamba sahayamu. Sesungguhnya Alloh tidak menyukai orang-orang yang sombong dan membangga-banggakan diri." (An-Nisa: 36). Dalam ayat ini Alloh menyebutkan hal-hal yang Dia perintahkan. Dan hal pertama yang Dia perintahkan adalah untuk menyembahNya dan tidak menyekutukanNya. Perintah ini didahulukan daripada berbuat baik kepada 
orang tua serta manusia-manusia pada umumnya. Maka sangatlah aneh jika seseorang bersikap sangat baik terhadap sesama manusia, namun dia banyak menyepelekan hak-hak Tuhannya terutama hak beribadah hanya kepada Alloh semata. 


\section{BAB III}

\section{PENUTUP}

\section{A. Kesimpulan}

1. Tauhid (Arab (ت وح يد), adalah konsep dalam aqidah Islam yang menyatakan keesaan Allah. Tauhid diambil kata : Wahhada Yuwahhidu Tauhidan yang artinya mengesakan. Satu suku kata dengan kata wahid yang berarti satu atau kata ahad yang berarti esa. Dalam ajaran Islam Tauhid itu berarti keyakinan akan keesaan Allah. Kalimat Tauhid ialah kalimat La Illaha Illallah yang berarti tidak ada Tuhan melainkan Allah. ( al-Baqarah:163, Muhammad 19 ). Tauhid merupakan inti dan dasar dari seluruh tata nilai dan norma Islam, sehingga oleh karenanya Islam dikenal sebagai agama tauhid yaitu agama yang mengesakan Tuhan.

2. Hakekat tauhid adalah kewajiban seluruh muslim untuk mengesakan Allah dan mengimplementasikannya dalam kehidupan sehari-hari. Kedudukannnya sangat penting karena tauhid inilah yang merupakan tujuan pertama diciptakannya manusia, diutusnya rasul dan tujuan pokok kehidupan manusia. Tauhid dibagi menjadi tiga jenis yaitu tauhid rububiyah, uluyiah dan tauhid asma wa sifat.

3. Tauhid sangat berpengaruh terhadap kehidupan seorang muslim, yaitu menjadi landasan kuat dalam menjalankan segala aktivitas, baik aktivitas keagamaan maupun aktivitas duniawi lainnya. Dengan tauhid seorang muslim akan menjalani kehidupannya dengan tenang, tawakal dan sabar. 
Oleh karena itu tauhid merupakan modal dasar bagi suksesnya seorang muslim baik di dunia maupun di akherat.

\section{B. Saran}

Setelah mengkaji masalah tauhid di atas, maka saran dari penulis khususnya bagi penulis sendiri, bahwa memegang teguh tauhid yaitu meyakini secara mutlak keesaan Allah merupakan modal utama dalam mengarungi kehidupan modern dewasa ini. Oleh karena itu, mempelajari tahuid yang sebenarnya merupakan keharusan bagi seorang muslim. 


\section{DAFTAR PUSTAKA}

Amin, Saidul. "Eksistensi Kajian Tauhid Dalam Keilmuan Ushuluddin." Majalah Ilmu Pengetahuan dan Pemikiran Keagamaan Tajdid 22, no. 1 (2019): 7183.

Alfajar, Muhammad Lutfi. "Nilai-nilai pendidikan tauhid dalam Kitab At-Tauhid Lish Shaffil Awwal Al-'Aliy karya Dr. Shalih bin Fauzan bin Abdullah AlFauzan." PhD diss., Universitas Islam Negeri Maulana Malik Ibrahim, 2016.

(http://id.islamiclopedia.org/wiki/Kitab_Tauhid-Tauhid)

(http://blog.re.or.id/tauhid-dan-korelasinya-dalam-menghapus-dosa.htm)

(http://halaqah.net/v10/index.php?action=printpage $;$ topic $=9800.0$ )

Via Al-Qur'an Indonesia https://quran-id.com

https://muslim.or.id/420-hakekat-tauhid.html 